\title{
Characterization and adsorption of a Lactobacillus plantarum virulent phage
}

\author{
X. Chen, ${ }^{1}$ J. Guo, Y. Liu, S. Chai, R. Ma, and B. Munguntsetseg \\ Key Laboratory of Dairy Biotechnology and Engineering, Ministry of Education, Key Laboratory of Dairy Products Processing, \\ Ministry of Agriculture, Inner Mongolia Agricultural University, Hohhot, 010018, P.R. China
}

\section{ABSTRACT}

Bacteriophage infection of lactic acid bacteria is considered one of the biggest worldwide problems in the food industry. Bacteriophages may cause negative effects on the fermentation of various dairy-based products. A virulent bacteriophage was isolated from an abnormal fermentation liquid of Lactobacillus plantarum IMAU10120. The characterization and influence of temperature, $\mathrm{pH}$, divalent cations, and chloramphenicol on the adsorption ability of this phage were evaluated. The results showed that this phage belonged to the $S i$ phoviridae family. It exhibited a burst time of $135 \mathrm{~min}$ and a burst size of approximately 215 counts expressed per milliliter per infective center. No significant effect was shown to influence its viability and adsorption at 10 to $37^{\circ} \mathrm{C}$. More than $90 \%$ of phages exhibited infectivity from $\mathrm{pH} 5$ to 9 . Divalent ions and chloramphenicol did not have a significant influence on the adsorption of this phage. The information obtained in this study will enrich the database of lactobacilli virulent phages and provide a basis of information for the control of phages in the food fermentation industry.

Key words: Lactobacillus plantarum virulent bacteriophage, tolerance, adsorption

\section{INTRODUCTION}

Bacteriophages of lactic acid bacteria have gained increasing attention over the past few decades because of their negative effects on the fermentation of various dairy-based products such as yogurt and cheese (Samson and Moineau, 2013). Starter culture failure or slow culture may result in significant economic losses in the dairy industry in terms of both time and starting material while also resulting in a poor-quality product with unacceptable organoleptic properties (Mahony et al., 2017). Phage contamination in fermentation vats has

\footnotetext{
Received November 20, 2018.

Accepted January 19, 2019.

${ }^{1}$ Corresponding author: chenxia8280@163.com
}

been reported to result from raw processed or recycled ingredients, including whey powder, air, and poorly sanitized process equipment. Today, the dairy industry has designed new protocols to detect and control phages (Garneau and Moineau, 2011).

Lysis of bacteria by phage consists of 5 basic steps: attachment, penetration, replication, virion assembly, and release. Adsorption is a key stage in virus recognition of a sensitive host cell, which can be divided into nonspecific and specific types (Rakhuba et al., 2010). Nonspecific adsorption between a phage and the bacterial surface is reversible, and external conditions such as temperature and $\mathrm{pH}$ are influential. Studies concerning the physiological and environmental factors on phage propagation and adsorption have been previously reported (Capra et al., 2006; Briggiler Marcó et al., 2010; Cvirkaitè-Krupovič et al., 2010; Mahony et al., 2015; Chen et al., 2016). In the event that the bacteriophage tail and bacterial surface receptor sites come together due to specific covalent binding, an irreversible adsorption process ensues. This step is a major factor contributing to the specificity of the phage to its host. Researchers have shown that carbohydrates, proteins, or both located in the bacterial cell membrane or cell wall can act as receptor sites that play an important role in the adsorption process (Bebeacua et al., 2013; McCabe et al., 2015). Therefore, alterations in the receptor structures can prevent the adsorption of a particular phage by increasing the host strain's resistance (Munsch-Alatossava and Alatossava, 2013).

Lactobacillus plantarum is used as a starter culture in many fermented milks, vegetables, and meats and is considered a major probiotic (Vries et al., 2006; Giraffa et al., 2010; Ferrando et al., 2015). Similar to other lactic acid bacteria, L. plantarum may be attacked by specific phages, resulting in lysis and subsequent slow or substandard fermentation. Recognizing the biological characteristics of related phages can provide a basis for mitigation protocols that could be used in the food industry. To date, information related to L. plantarum phages is limited.

Lactobacillus plantarum IMAU 10120 is a starter culture that exhibits several desirable properties, such as 
high acid and bile tolerance, good aggregation, antibacterial activities, high soy milk fermentation efficiency, and strong stability upon storage. Chen et al. (2016) isolated a Lactobacillus virulent phage (P1) from its abnormal fermented liquid and researched its biological properties and the influence of physicochemical parameters on its adsorption. Unfortunately, the abnormal fermentation occurred again, and a new bacteriophage (P2) was isolated. The aim of the present study was to evaluate the characteristics and influence of various physicochemical parameters on the viability and adsorption ability of phage P2.

\section{MATERIALS AND METHODS}

\section{Bacterial Strains, Phage, and Culture Condition}

Phage P2 was initially isolated from the broth culture of a slowly fermenting L. plantarum IMAU 10120 (Lactic Acid Bacteria Collection Center in the Key Laboratory of Dairy Biotechnology and Engineering, Ministry of Education, Inner Mongolia Agricultural University, Hohhot, P.R. China). The host strain, L. plantarum IMAU10120, was grown at $37^{\circ} \mathrm{C}$ in de Man, Rogosa and Sharpe (MRS) broth (Becton Dickinson, Franklin Lakes, NJ). We used MRS broth supplemented with $10 \mathrm{~m} M \mathrm{CaCl}_{2}$ (MRS-Ca broth) for phage amplification. Phage stocks were prepared as described previously (Neviani et al., 1992) and stored as lysates at $4^{\circ} \mathrm{C}$. Phage counts were obtained using a doublelayer plaque titration method and expressed in plaqueforming units per milliliter by the methods described by Quiberoni et al. (2011) with some modification. In brief, $100 \mu \mathrm{L}$ of phage suspension was mixed with host bacteria suspended in a top layer of melted MRS agar (20 mL, 0.7\% wt/vol agar) containing $10 \mathrm{mM} \mathrm{CaCl} 2$ and maintained at $46^{\circ} \mathrm{C}$. The top layer was immediately poured into Petri dishes $(90 \mathrm{~mm})$ containing a bottom agar of MRS agar (1.5\% wt/vol agar). All plates were incubated at $37^{\circ} \mathrm{C}$ for 16 to $18 \mathrm{~h}$ before they were examined for plaques.

\section{Electron Microscopy}

Phage electron micrographs were obtained according to De Antoni et al. (2010). Phage suspensions were concentrated by centrifugation $\left(1 \mathrm{~h}, 70,000 \times g, 5^{\circ} \mathrm{C}\right)$ and stained using either uranyl acetate $(2 \%$ wt/vol, $\mathrm{pH} 4.5)$ or phosphotugstic acid $(2 \% \mathrm{wt} / \mathrm{vol})$. Electron micrographs were taken using a Jeol H-7000 electron microscope (Jeol USA Inc., Peabody, MA) operating at $75 \mathrm{kV}$. Phage morphology, capsid diameter, and tail length and width were recorded.

\section{1-Step Growth Curve}

Lactobacillus plantarum IMAU10120 was grown to the exponential phase (optical density at $600 \mathrm{~nm}=$ 0.5 ) and harvested by centrifugation. The pellet was subsequently resuspended in $100 \mu \mathrm{L}$ of MRS-Ca broth. Phages were added at a multiplicity of infection (MOI) of 2. After adsorption $\left(15 \mathrm{~min}\right.$ at $\left.37^{\circ} \mathrm{C}\right)$, cells were harvested by centrifugation $(10,000 \times g$ for $5 \mathrm{~min})$ at room temperature. The resulting pellet was resuspended in MRS-Ca broth and incubated at $37^{\circ} \mathrm{C}$. At regular intervals (15 min), $100 \mu \mathrm{L}$ of each dilution was collected for phage enumeration (Capra et al., 2006). The latent period, burst time, and burst size were calculated from a 1-step growth curve.

\section{Influence of Temperature on Phage Viability}

Phages $\left(10^{7} \mathrm{pfu} / \mathrm{mL}\right)$ were suspended in MRS broth, placed into Eppendorf tubes (1 mL final volume), and incubated at $0,10,20,30,37,42$, and $50^{\circ} \mathrm{C}$ for 30 min. The surviving phages were immediately counted as previously described, and the results were expressed as a percentage of remaining phage counts versus initial phage counts.

\section{Influence of $\mathrm{pH}$ on Phage Viability}

Phages $\left(10^{7} \mathrm{pfu} / \mathrm{mL}\right)$ were suspended in MRS broth at a $\mathrm{pH}$ from 2 to 11, placed into Eppendorf tubes (1 $\mathrm{mL}$ final volume), and incubated at $37^{\circ} \mathrm{C}$ for $30 \mathrm{~min}$. The surviving phages were immediately counted as previously described. The results were expressed as a percentage of remaining phage counts versus the initial phage counts.

\section{Influence of Temperature on Phage Adsorption}

The influence of temperature on the adsorption of phage was determined at $0,10,20,30,37,42$, and $50^{\circ} \mathrm{C}$. Lactobacillus plantarum cultures $(\mathrm{MOI}=0.5)$ were suspended in MRS broth with incubation at $30 \mathrm{~min}$. Plaque formation was investigated using the doublelayer plaque technique as previously described. Results are expressed as the percentage of adsorption after 30 min and plotted against temperature values.

\section{Influence of $\mathrm{pH}$ on Phage Adsorption}

The influence of $\mathrm{pH}$ (from 4 to 11) on cell lysis was evaluated by incubating L. plantarum $(\mathrm{MOI}=0.5)$ cultures in MRS broth at $37^{\circ} \mathrm{C}$ for 30 min. Plaque for- 
mation was investigated using the double-layer plaque technique as previously described. Results are expressed as a percentage of adsorption after $30 \mathrm{~min}$ and plotted against $\mathrm{pH}$ values.

\section{Influence of Divalent Cations on Phage Adsorption}

The influence of $\mathrm{Ca}^{2+}$ and $\mathrm{Mg}^{2+}$ on cell lysis was evaluated by incubating L. plantarum $(\mathrm{MOI}=0.5)$ in MRS broth with and without $\mathrm{CaCl}_{2}$ or $\mathrm{MgCl}_{2}(10$ $\mathrm{mmol} / \mathrm{L}$ ) at $37^{\circ} \mathrm{C}$. At intervals of 0,15 , and $30 \mathrm{~min}$, tubes were centrifuged $(10,000 \times g$ for $5 \mathrm{~min})$ and the supernatants were analyzed for unabsorbed phages using a double-layer plate titration method as previously described. Counts were compared with the titer of a control without cells. The results are expressed as a percentage of adsorbed phage to initial phage.

\section{Influence of Cell Protein Synthesis Inhibitors on Phage Adsorption}

The minimum concentration of chloramphenicol needed to inhibit protein synthesis in L. plantarum IMAU10120 was determined as described by Briggiler Marcó et al. (2010). Host cells were treated with chloramphenicol $(20 \mu \mathrm{g} / \mathrm{mL})$, and the chloramphenicol was removed after the inhibition of protein synthesis was achieved. Treated cells were infected with phage $(\mathrm{MOI}=0.5)$ and then incubated at $37^{\circ} \mathrm{C}$ for $30 \mathrm{~min}$. After centrifugation $(10,000 \times g$ for $5 \mathrm{~min})$, the titers of unadsorbed free phages in the supernatants were assayed as indicated, and the results were expressed as percentages of the adsorption. A cell culture subjected to a similar treatment but without chloramphenicol was used as adsorption control.

\section{Statistical Analysis}

All data were analyzed using Originpro software (8.6, Originlab, Originlab Corp., Northampton, MA). Experiments were replicated 3 times. Means were compared using the 1-way ANOVA procedure in SPSS (version 20.0.0, IBM Corp., Armonk, NY) at $P<0.05$.

\section{RESULTS AND DISCUSSION}

\section{Electron Microscopy}

Phage infection is considered to be one of the most prevalent reasons for starter culture failure in the fermentation production of dairy and meat products, which may cause economic losses for the manufacturers.
Research on their characteristics has therefore become important for the development of new phage control strategies. Phage P2 was isolated from the abnormal fermented liquid of L. plantarum IMAU 10120. Its electron micrograph is shown in Figure 1. The results showed that this phage had an isometric capsid of approximately $66.7 \pm 3.0 \mathrm{~nm}$ and a long noncontractile tail (approximately $216.7 \pm 3.0 \mathrm{~nm}$ long and $12.3 \pm 3.0$ $\mathrm{nm}$ wide). Based on its morphology, it was ascribed to the Siphoviridae family, which is frequently associated with lactic acid bacteria phages (Dieterle et al., 2014).

In 2016, phage P1 was isolated from the same host strain with characteristics similar to those belonging to the Siphoviridae family. A major difference between phages P1 and P2 was size. Phage P1 was larger, with an isometric capsid of $71.7 \pm 3.0 \mathrm{~nm}$ and long noncontractile tails (approximately $272 \pm 3.0 \mathrm{~nm}$ long and 11.3 $\pm 1.5 \mathrm{~nm}$ wide; Chen et al., 2016). Ackermann (2007) also reported that for various Lactobacillus phages, almost $60 \%$ belonged to the Siphoviridae family. Villion and Moineau (2009) reported that of 24 L. plantarum phages identified, 19 belonged to the Siphoviridae family; the remaining were classified as belonging to the Myoviridae family.

\section{1-Step Growth Curve}

Figure 2 shows the 1-step growth curve of phage P2. The latent period was 30 min with a burst time of $135 \mathrm{~min}$. The burst size was $214.5 \pm 4.0 \mathrm{pfu} /$ infective center. For phage P1, which was isolated from the same host strain, the latent time was 45 min, the burst time was $90 \mathrm{~min}$, and the burst size was $132.88 \pm 2.37 \mathrm{pfu} /$ infective center (Chen et al., 2016). Compared with phage $\mathrm{P} 1$, phage $\mathrm{P} 2$ showed a shorter latent time, longer burst time, and higher burst size.

In 2015, Zhang et al. (2015) isolated a virulent phage (Lcb) of Lactobacillus casei ATCC 393 and reported a latent period of approximately $75 \mathrm{~min}$, followed by a relatively short burst period of $45 \mathrm{~min}$; the burst size was approximately $16 \mathrm{pfu} /$ infective center at $30^{\circ} \mathrm{C}$. Sunthornthummas et al. (2017) reported a 55-min latent period for $L$. paracasei phage $\Phi \mathrm{T} 25$ at $37^{\circ} \mathrm{C}$, followed by a 55-min rise period and an average burst size of approximately 38 phage particles per infected cell. In 2009, Villion and Moineau (2009) reviewed the characteristics of 8 L. plantarum phages and found that only 1 phage, fri, which was isolated from the L. plantarum portion of a commercial meat starter culture, expressed a burst size of $200 \mathrm{pfu} /$ infective center. For phage $\mathrm{P} 2$, it expressed a short latent period (30 min) at $37^{\circ} \mathrm{C}$, followed by $105-\mathrm{min}$ rise period and an average 


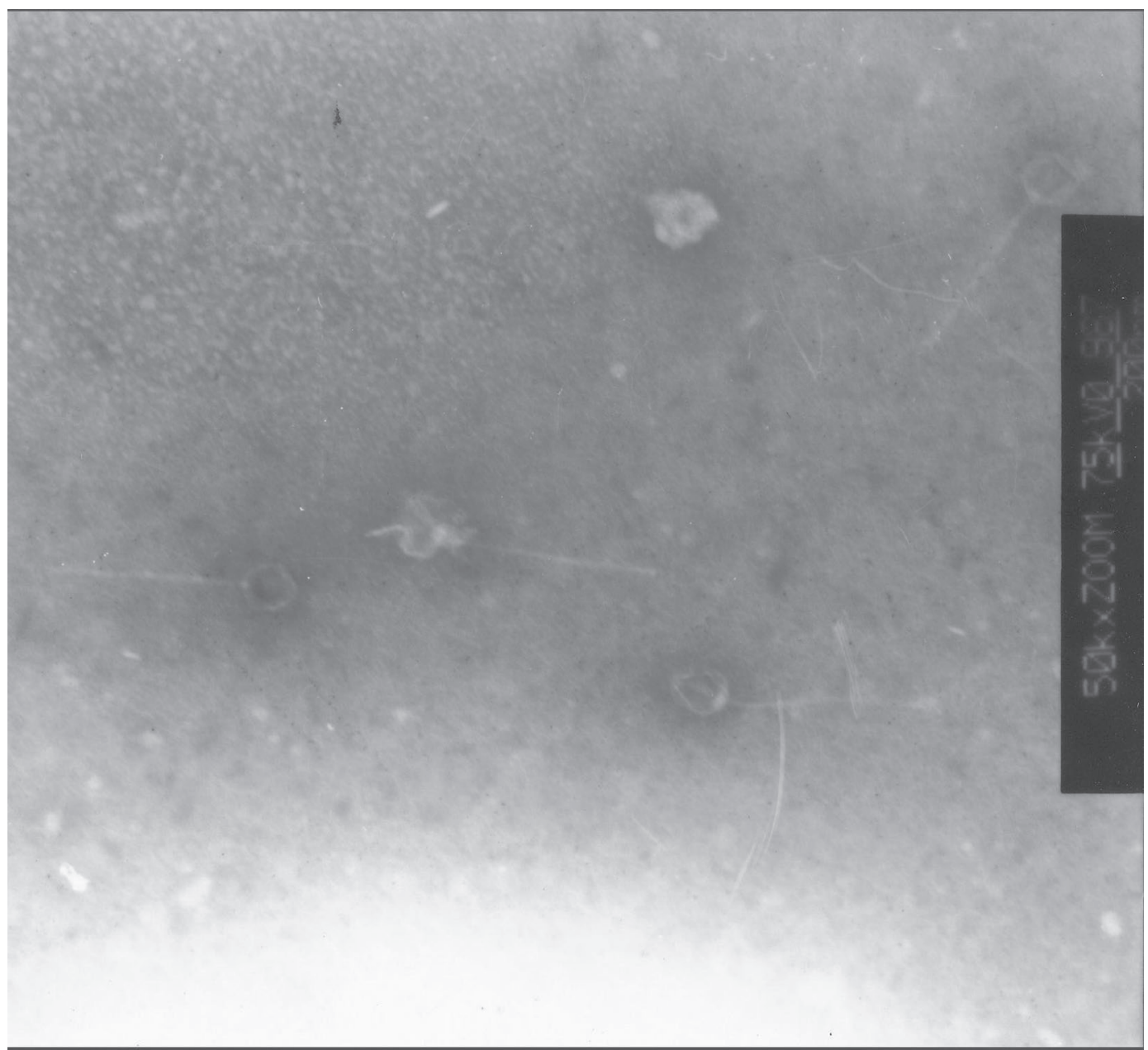

Figure 1. Electron micrograph of Lactobacillus plantarum phage P2.

burst size of approximately $214.5 \mathrm{pfu} /$ infective center. If $L$. plantarum phage P2 contaminates fermentation, it might result in severe effects.

\section{Influence of Temperature on Phage Viability}

Temperature plays a fundamental role in attachment, penetration, multiplication, and the length of the latent period (Jończyk et al., 2011). Figure 3 shows the influence of temperature on the viability of phage P2. No significant effect $(P<0.05)$ on viability was demonstrated at temperatures of 10 to $37^{\circ} \mathrm{C}$. However, when the temperature was reduced to $0^{\circ} \mathrm{C}$ or increased to $42^{\circ} \mathrm{C}$, the survival rate was significantly reduced. The survival rate decreased to approximately $13 \%$ following incubation at $50^{\circ} \mathrm{C}$ for $30 \mathrm{~min}$.

The results obtained in this study indicated that the previous phage, $\mathrm{P} 1$, isolated from the same bacterium was more temperature resistant compared with P2

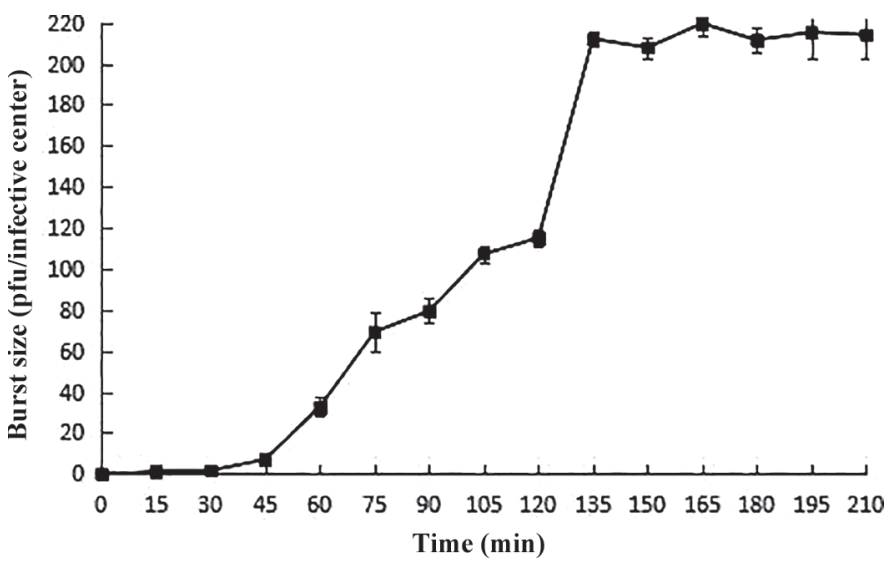

Figure 2. One-step growth curve of Lactobacillus plantarum phage P2. Error bars represent 95\% CI. 


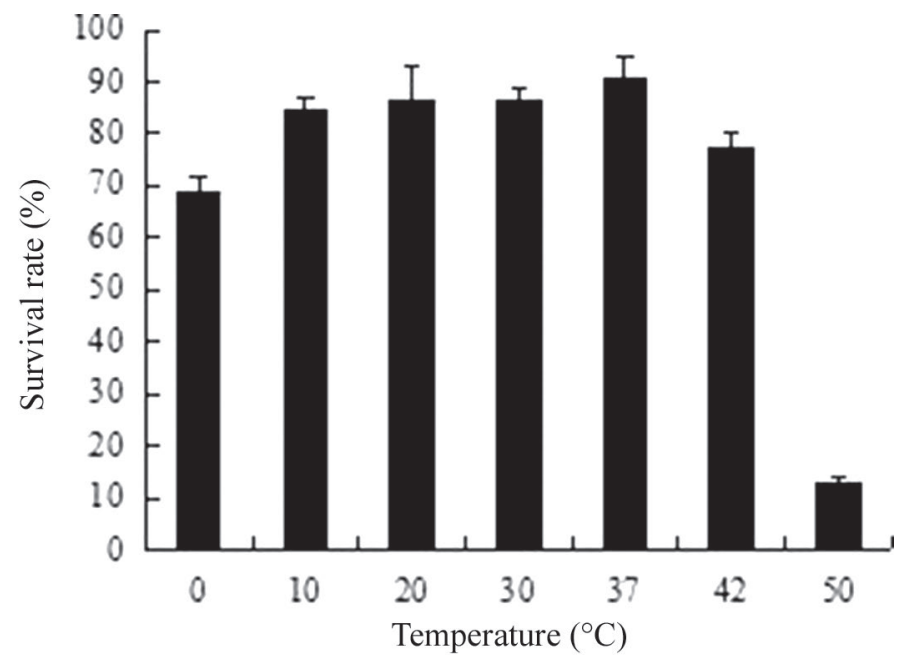

Figure 3. Survival rate of phage P2 after 30 min in de Man, Rogosa and Sharpe broth at different temperatures. The values are the mean of 3 determinations. Error bars represent 95\% CI.

because incubation at $50^{\circ} \mathrm{C}$ for 30 min still resulted in 95\% viability (Chen et al., 2016). Briggiler Marcó et al. (2010) evaluated the influence of temperature $\left(0,10,20,30,37,42\right.$, and $\left.50^{\circ} \mathrm{C}\right)$ on infectivity of 4 L. plantarum phages (B1, B2, FAGK1, and FAGK2). The author reported that these temperatures did not appear to influence the infectivity of these phages. In contrast to the results obtained in the present study, more than $95 \%$ of the initial phages remained viable after $30 \mathrm{~min}$ in $\mathrm{MRS}$ broth at $50^{\circ} \mathrm{C}$.

\section{Influence of $\mathrm{pH}$ on Phage Viability}

As shown in Figure 4, more than $80 \%$ of the phages remained infective over a $\mathrm{pH}$ range from 6 to 9 . However, decreases in phage viability at $\mathrm{pH}$ values below 6 and above 9 were quite apparent. No viable phage was observed at $\mathrm{pH} 2$ to 3 .

\section{Influence of Temperature on Phage Adsorption}

Figure 5 shows the influence of temperature on the adsorption of phage P2. Temperatures from 0 to $42^{\circ} \mathrm{C}$ did not appear to influence phage adsorption because more than $88 \%$ of phage particles were adsorbed after 30 min. Incubated at $50^{\circ} \mathrm{C}$, unadsorbed phage particles increased to $31.33 \%$. Similar to other Lactobacillus phages, the highest adsorption rate was achieved at $37^{\circ} \mathrm{C}(92.81 \%)$.

For the influence of temperature on phage adsorption of phage P2, similar results were previously reported

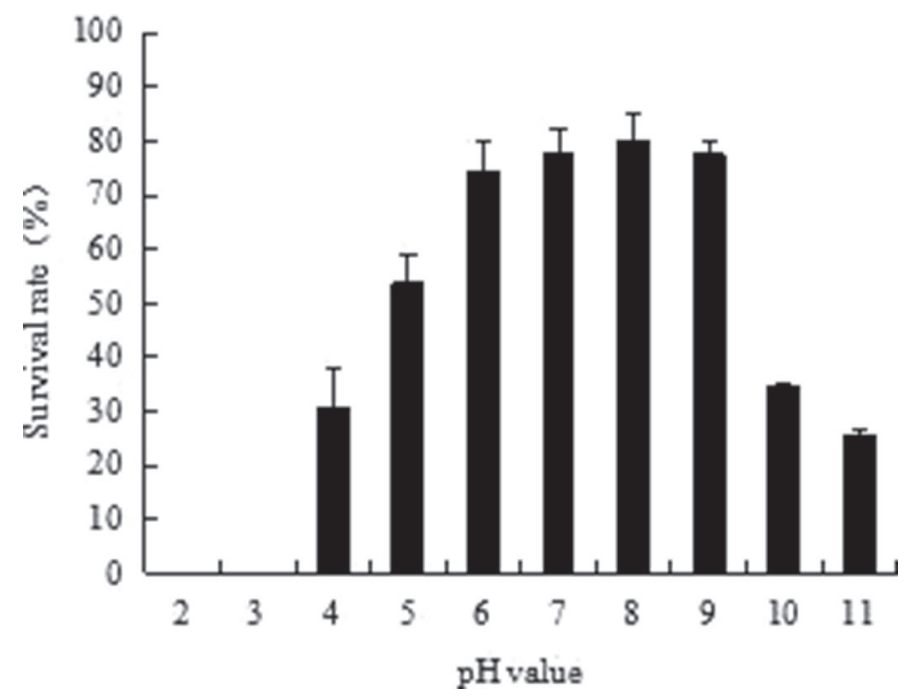

Figure 4. Effect of $\mathrm{pH}$ on survival rate of phage P2 in de Man, Rogosa and Sharpe broth after $30 \mathrm{~min}$ at $37^{\circ} \mathrm{C}$. The values are the mean of 3 determinations. Error bars represent $95 \%$ CI.

for L. plantarum phages by Chen et al. (2016) and Briggiler Marcó et al. (2010). Chen et al. (2016) reported that more than $85 \%$ of phage $\mathrm{P} 1$ were adsorbed after $45 \mathrm{~min}$ at all temperatures tested $(0,10,20,30$, 37 , and $42^{\circ} \mathrm{C}$ ) except at $50^{\circ} \mathrm{C}$. Briggiler Marcó et al. (2010) evaluated the influence of temperature on the adsorption of 4 phages of L. plantarum ATCC8014. They found that more than $82 \%$ phage particles were adsorbed after $30 \mathrm{~min}$ in all the conditions studied except at $50^{\circ} \mathrm{C}$, which caused an increase in the titers of

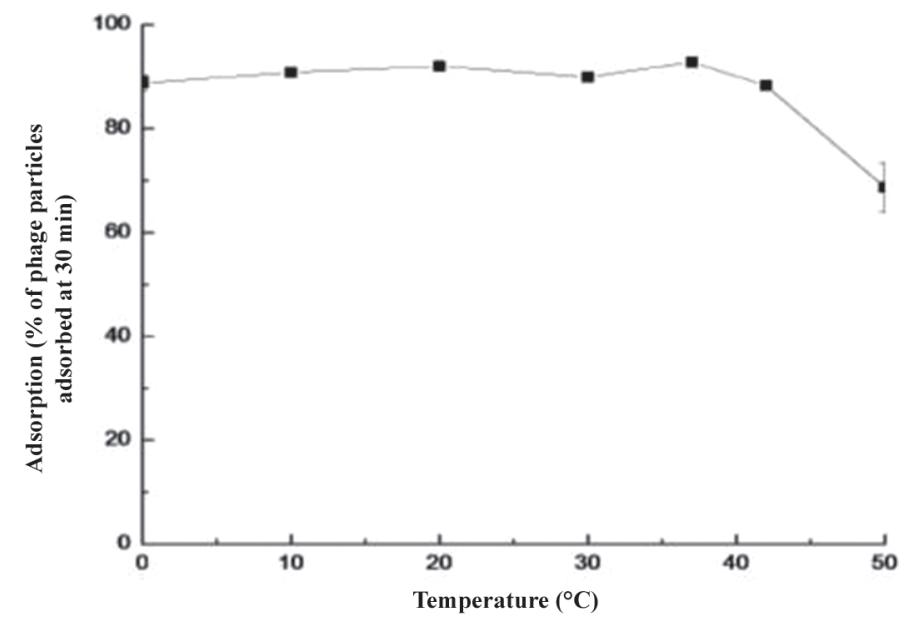

Figure 5. Influence of temperature on the adsorption of phage P2 after 30 min in de Man, Rogosa and Sharpe broth. Values are the means of 3 determinations. Error bars represent 95\% CI. 
unadsorbed phages particles (adsorption values $<39 \%$ ), and the maximum adsorption values were achieved at temperatures ranging from 30 to $42^{\circ} \mathrm{C}$ for all phages (Briggiler Marcó et al., 2010). For L. paracasei phages ФiLp84 and $\Phi$ iLp 1308, the efficiency of adsorption was minimal at $0^{\circ} \mathrm{C}$ and increased with temperature up to $37^{\circ} \mathrm{C}$ (Mercanti et al., 2015). It has been suggested that the effect of temperature on phage propagation could be due to temperature-dependent changes in the bacterial cell wall. This could affect the adsorption of phages, and temperatures of 30 and $37^{\circ} \mathrm{C}$ may be more effective (Caso et al., 1995). Moreover, higher temperature may prolong the length of the latent stage (Tey et al., 2009).

\section{Influence of $\mathrm{pH}$ on Phage Adsorption}

The influence of $\mathrm{pH}$ on phage adsorption is shown in Figure 6. No significant $(P<0.05)$ effect on phage adsorption was observed from $\mathrm{pH} 5$ to 9 ; in all cases adsorption approached 90\%. In contrast, the adsorption rate decreased to approximately 77 and $67 \%$ at $\mathrm{pH}$ 4 and 10, respectively.

For the influence of $\mathrm{pH}$ on the viability and adsorption of Lactobacillus phages, similar results have been reported. For example, phage P1 also exhibited more than $90 \%$ survival at $\mathrm{pH}$ values from 6 to 8; however, only $1.2 \%$ survival was observed at $\mathrm{pH} 3$ following 30 min incubation at $37^{\circ} \mathrm{C}$. Moreover, more than $90 \%$ adsorption occurred from a $\mathrm{pH}$ of 4 to 8 . When the $\mathrm{pH}$ increased to 11, the adsorption rate decreased to $7.78 \%$ after 45 min (Chen et al., 2016). For phages B1, B2, FAGK1, and FAGK2, the highest viability $(>80 \%)$ was observed in a wider $\mathrm{pH}$ range (from 5 to 11); however, complete inactivation was observed after $30 \mathrm{~min}$ at $\mathrm{pH}$ 2. The highest adsorption values for these 4 phages occurred at $\mathrm{pH} 5$ to 7 after $30 \mathrm{~min}$ at $37^{\circ} \mathrm{C}$. At $\mathrm{pH} 9$, the extent of adsorption for phage B1 ranged from $23 \%$ (phage B1) to $45 \%$ (phage B2), whereas at $\mathrm{pH} 10$, the adsorption value was less than 20\% (Briggiler Marcó et al., 2010). Sunthornthummas et al. (2017) reported that phage $\Phi \mathrm{T} 25$ was also resistant to a wide range of $\mathrm{pH}$; however, no survivors could be detected following incubation at $\mathrm{pH} 2$ for $30 \mathrm{~min}$ at $37^{\circ} \mathrm{C}$. Phage $\mathrm{P} 2$ was more sensitive to higher $\mathrm{pH}$ value than to lower $\mathrm{pH}$ value. Compared with previous results, the adsorption of phage $\mathrm{P} 2$ was more stable under high $\mathrm{pH}$ values. When the $\mathrm{pH}$ value increased to 11 , its adsorption rate was still $61.14 \%$ after 30 min of treatment. Langlet et al. (2007) reported that MS2 phages showed significant ability to aggregate when the $\mathrm{pH}$ was less than or equal to the phage isoelectric point. This could cause a decline in phage count and the adsorption on membranes (Jończyk et al., 2011).

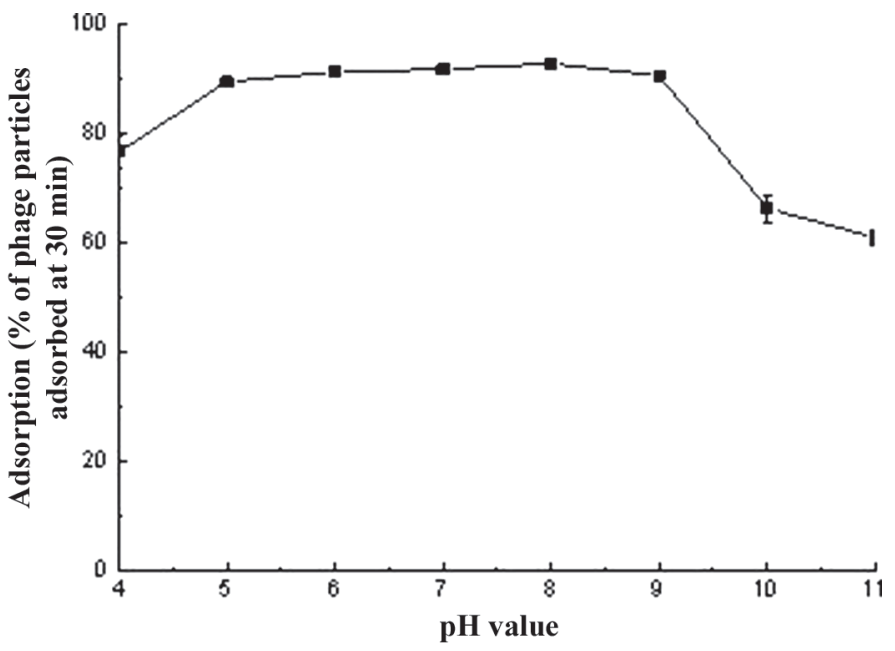

Figure 6. Influence of $\mathrm{pH}$ on the adsorption of phage P2 after 30 min in de Man, Rogosa and Sharpe broth. Values are the means of 3 determinations. Error bars represent 95\% CI.

\section{Influence of Divalent Cations on Phage Adsorption}

$\mathrm{Ca}^{2+}$ or $\mathrm{Mg}^{2+}$ cations are recognized as necessary for proliferation of phages (Zhang et al., 2015). As shown in Figure 7, cell lysis in MRS broth occurred even without divalent cations but can form clear lysis plaques after 30 -min treatments in the presence of $\mathrm{Ca}^{2+}$. In general, calcium ions did not have a significant $(P>0.05)$ influence on phage adsorption kinetics (Figure 7).

For other reported phages, we found that the requirement of divalent cations for phage adsorption was variable. Similar to our reports, Briggiler Marcó et al. (2010) reported that divalent cations were not necessary for adsorption or completion of the lytic cycle of the 4

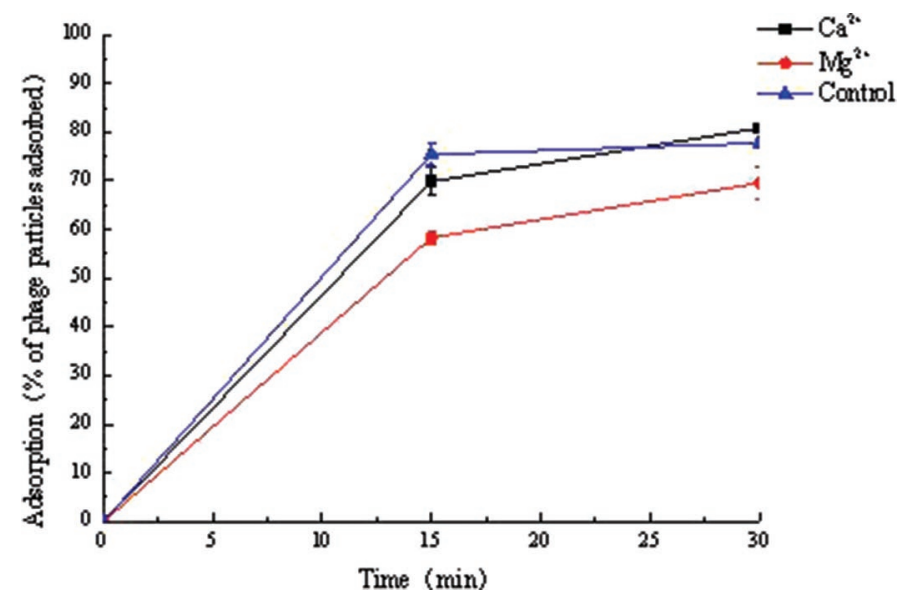

Figure 7. Influence of divalent cations on adsorption of phage P2 after $30 \mathrm{~min}$ at $37^{\circ} \mathrm{C}$. Values are the mean of 3 determinations. Error bars represent $95 \%$ CI. 
L. plantarum phages (B1, B2, FAGK1, and FAGK2). In contrast, Zhang et al. (2015) found that although $\mathrm{Ca}^{2+}$ and $\mathrm{Mg}^{2+}$ were not necessary for the completion of the lytic cycle of phage Lcb of Lactobacillus casei ATCC393, they did improve complete lysis and plaque formation. Sunthornthummas et al. (2017) reported that the addition of calcium ions affected the adsorption of phage $\Phi \mathrm{T} 25$ because maximum adsorption rates were observed in the presence of $20 \mathrm{mM}$ calcium ions after 30 min of incubation. It was suggested that calcium ions could stabilize the DNA inside the phage capsid as well as control the penetration of phage DNA into host cells (Zhang et al., 2015).

\section{Influence of Cell Protein Synthesis Inhibitors on Phage Adsorption}

The chloramphenicol concentration used in this study was $20 \mu \mathrm{g} / \mathrm{mL}$. The results showed that treatment of chloramphenicol did not affect its adsorption $(P>0.05)$ on cells compared with untreated cells. After $30 \mathrm{~min}$ of incubation, more than $90 \%$ of initial phage particles were adsorbed with or without chloramphenicol (data not shown). This result was similar to previous reports of L. plantarum phages (Briggiler Marcó et al., 2010; Chen et al., 2016). As previously reported, it would not be expected that phage binding is an energy-dependent process. Further studies will be needed to recognize the phage receptor sites.

\section{CONCLUSIONS}

A virulent phage P2 belonging to the Siphoviridae family was isolated from the abnormal fermented liquid of L. plantarum IMAU10120. This research revealed its important properties and evaluated the influence of physicochemical factors on its viability and adsorption rate. The latent period of this phage was 30 min with a burst time of $135 \mathrm{~min}$. Its burst size was $214.5 \pm 4.0$ pfu/infective center. Temperatures of 10 to $37^{\circ} \mathrm{C}$ had little effect on its viability and adsorption. More than $90 \%$ of phages exhibited infectivity from $\mathrm{pH} 5$ to 9 . Divalent cations and chloramphenicol did not significantly affect its adsorption. Further studies will focus on researching the infective mechanism of this phage as well as effective strategies to control phage infections in industry.

\section{ACKNOWLEDGMENTS}

This work was supported by Natural Science Foundation of China (grant no. 31760447, 31301517, Beijing, China) and Natural Science Foundation of Inner
Mongolia, China (grant no. 2017MS0308, 2013MS1207, Hohhot, China).

\section{REFERENCES}

Ackermann, H. W. 2007. 5500 phages examined in the electron microscope. Arch. Virol. 152:227-243.

Bebeacua, C., D. Tremblay, C. Farenc, M. Chapot-Chartier, I. Sadovskaya, M. van Heel, D. Veesler, S. Moineau, and C. Cambillau. 2013. Structure, adsorption to host, and infection mechanism of virulent lactococcal phage p2. J. Virol. 87:12302-12312.

Briggiler Marcó, M., J. A. Reinheimer, and A. Quiberoni. 2010. Phage adsorption to Lactobacillus plantarum: Influence of physiological and environmental factors. Int. J. Food Microbiol. 138:270-275.

Capra, M. L., A. Quiberoni, and J. Reinheimer. 2006. Phages of Lactobacillus casei/paracase $i$ : Response to environmental factors and interaction with collection and commercial strains. J. Appl. Microbiol. 100:334-342.

Caso, J. L., C. G. D. L. Reyes-Gavilan, M. Herrero, A. Montilla, A. Rodriguez, and J. E. Suarez. 1995. Isolation and characterization of temperate and virulent bacteriophages of Lactobacillus plantarum. J. Dairy Sci. 78:741-750.

Chen, X., Y. Xi, H. Zhang, Z. Wang, M. Fan, Y. Liu, and W. Wu. 2016. Characterization and adsorption of Lactobacillus virulent phage P1. J. Dairy Sci. 99:6995-7001.

Cvirkaitė-Krupovič, V., M. Krupovič, R. Daugelavičius, and D. H. Bamfor. 2010. Calcium ion-dependent entry of the membranecontaining bacteriophage PM2 into its Pseudoalteromonas host. Virology 405:120-128.

De Antoni, G., M. Zago, O. Vasek, G. Giraffa, D. Carminati, M. Briggiler Marcó, J. Reinheimer, and V. Suárez. 2010. Lactobacillus plantarum bacteriophages isolated from kefir grains: Phenotypic and molecular characterization. J. Dairy Res. 77:7-12.

Dieterle, M. E., C. Bowman, C. Batthyany, E. Lanzarotti, A. Turjanski, G. Hatfull, and M. Piuri. 2014. Exposing the secrets of two well-known Lactobacillus casei phages, J-1 and PL-1, by genomic and structural analysis. Appl. Environ. Microbiol. 80:7107-7121.

Ferrando, V., A. Quiberoni, J. Reinhemer, and V. Suárez. 2015. Resistance of functional Lactobacillus plantarum strains against food stress conditions. Food Microbiol. 48:63-71.

Garneau, J. E., and S. Moineau. 2011. Bacteriophages of lactic acid bacteria and their impact on milk fermentations. Microb. Cell Fact. 10(Suppl. 1):S20.

Giraffa, G., N. Chanishvili, and Y. Widyastuti. 2010. Importance of lactobacilli in food and feed biotechnology. Res. Microbiol. 161:480-487

Jończyk, E., M. Klak, R. Międzybrodzki, and A. Górski. 2011. The influence of external factors on bacteriophages-Review. Folia Microbiol. (Praha) 56:191-200.

Langlet, J., F. Gaboriaud, and C. Gantzer. 2007. Effects of pH on plaque forming unit counts and aggregation of MS2 bacteriophage. J. Appl. Microbiol. 103:1632-1638.

Mahony, J., C. Cambillau, and D. van Sinderen. 2017. Host recognition by lactic acid bacterial phages. FEMS Microbiol. Rev. 41:S16-S26.

Mahony, J., D. M. Tremblay, S. J. Labrie, S. Moineau, and D. van Sinderen. 2015. Investigating the requirement for calcium during lactococcal phage infection. Int. J. Food Microbiol. 201:47-51.

McCabe, O., S. Spinelli, C. Farenc, M. Labbé, D. Tremblay, S. Blangy, S. Oscarson, S. Moineau, and C. Cambillau. 2015. The targeted recognition of Lactococcus lactis phages to their polysaccharide receptors. Mol. Microbiol. 96:875-886.

Mercanti, D. J., H. W. Ackermann, and A. Quiberoni. 2015. Characterization of two temperate Lactobacillus paracasei bacteriophages: Morphology, kinetics and adsorption. Intervirology 58:49-56.

Munsch-Alatossava, P., and T. Alatossava. 2013. The extracellular phage-host interactions involved in the bacteriophage LL-H infection of Lactobacillus delbrueckii ssp. lactis ATCC 15808. Front. Microbiol. 4:408. 
Neviani, E., D. Carminati, and G. Giraffa. 1992. Selection of some bacteriophage and lysozyme-resistant variants of Lactobacillus helveticus CNRZ 892. J. Dairy Sci. 75:905-913.

Quiberoni, A., V. B. Suárez, A. G. Binetti, and J. A. Reinheimer 2011. Bacteriophage. Pages 430-438 in Encyclopedia of Dairy Science. 2nd ed. Vol. 1. J. Fuquay, P. Fox, and P. McSweeney, ed. Academic Press, Wageningen, the Netherlands.

Rakhuba, D. V., E. I. Kolomiets, E. S. Dey, and G. I. Novik. 2010. Bacteriophage receptors, mechanisms of phage adsorption and penetration into host cell. Pol. J. Microbiol. 59:145-155.

Samson, J. E., and S. Moineau. 2013. Bacteriophages in food fermentations: New frontiers in a continuous arms race. Annu. Rev. Food Sci. Technol. 4:347-368.

Sunthornthummas, S., K. Doi, A. Rangsiruji, S. Sarawaneeyaruk, and O. Pringsulaka. 2017. Isolation and characterization of Lactobacil- lus paracasei LPC and phage $\Phi \mathrm{T} 25$ from fermented milk. Food Control 73:1353-1361

Tey, B. T., S. T. Ooi, K. C. Yong, M. Ng, T. C. Ling, and W. S. Tan. 2009. Production of fusion M13 phage bearing the di-sulphide constrained peptide sequence (C-WSFFSNI-C) that interacts with hepatitis B core antigen. Afr. J. Biotechnol. 8:268-273.

Villion, M., and S. Moineau. 2009. Bacteriophages of Lactobacillus. Front. Biosci. (Landmark Ed.) 14:1661-1683.

Vries, M. C. D., E. E. Vaughan, M. Kleerebezem, and W. M. D. Vos, 2006. Lactobacillus plantarum - Survival, functional and potential probiotic properties in the human intestinal tract. Int. Dairy J. 16:1018-1028.

Zhang, X., Y. Lan, W. Jiao, Y. Li, L. Tang, Y. Jiang, W. Cui, and X. Qiao. 2015. Isolation and characterization of a novel virulent phage of Lactobacillus casei ATCC 393. Food Environ. Virol. 7:333-341. 